\title{
Cloud Computing Environments Which Can Be Used in Health Education
}

\author{
Mustafa Buber*1, Fadime Sucu ${ }^{2}$, Ismail Bulut ${ }^{3}$, Ramazan Kursun ${ }^{4}$ \\ Accepted $15^{\text {th }}$ August $2015 \quad$ DOI: 10.18201/ijisae.92756
}

\begin{abstract}
At the present time, it is known that cloud computing technologies began to be used widely in information technology. The purpose of this study is to provide information about cloud technologies that can be used in health education. For this purpose,firstly as sample of the learning content management system, Edmodo has been introduced. Hapyak Interactive Video Creation Platform which can be used for creating interactive video to enrich the learning environment that will be submitted with Edmodo, Bubbl.Us which can be benefited from summarizing the discussed and Socrative platforms which enable concept maps application and online test creation have been introduced.
\end{abstract}

Keywords: Cloud Computing, Edmodo, Health Education.

\section{Introduction}

In today information technology, it is known that "cloud computing" concept is frequently used. It is said to have opened a new and different era in information technology for those interested in cloud computing (Kavzoğlu \& Şahin, 2012). Cloud computing is defined submission of sources as software or hardware by means easily manageable via the web-based services to be available for public use. (Elitaş \& Ozdemir, 2014).

Soykan (2013) stated that submitted cloud technology services can be examined in three categories. These are infrastructure services, platform services and software / applications services. Infrastructure cloud services offer services aimed at users' storage needs, services to supply the needs of networking and server services. In a sense, the opening of the joint use of hardware resources by virtual storage. Platform cloud services offer services that enable development environment to the user. Software / application cloud services is a type of service that offer all the services and infrastructure which are provided by server and remain using only software for user.

In particular, services that you pay only as far as how much you have used instead of buying the software on condition that sharewares are required, can be exemplify as cloud services. The main benefits of cloud computing that widely offers services for different purposes are described as follows (Turan, 2014):

1. Flexibility
a. Being flexible and adaptable,
b. Being able to respond quickly,
c. Being able to provide efficient services

${ }^{1}$ Doganhisar Vocational School, University of Selcuk, Konya, Turkey ${ }^{2}$ Computer Education and Instructional Technology Department, University of Gaziosmanpasa, Tokat, Turkey

${ }^{3}$ Division of Curriculum and Instruction, University of Duzce, Duzce, Turkey

${ }^{4}$ Guneysinir Vocational School, University of Selcuk, Konya, Turkey

*Corresponding Author: Email: mbuber@ selcuk.edu.tr

Note :This paper has been presented at the International Conference on Advanced Technology\&Sciences (ICAT'15) held in Antalya (Turkey), August 04-07, 2015.
2. Cost

a. Cost / Qualify suitability,

b. Being economical of access tools

3. Quality of Service

a. Offering reliable services,

b. Being sustainable services

In many areas in Turkey and in the world, people are interested in cloud computing services and benefit from the innovations that it brought (Y1ld1z, 2010). The cloud information services that affect many area, health education can not be considered without cloud information services. In this study, cloud technologies will be introduced that will allow health educators to submit educational environment or material.

\subsection{EDMODO}

Edmodo that all common shares are collected at a single point, is a learning and teaching tool that enables remote management of classes and designed for totally educational purpose. It is a free and online platform that provides to be given over the web of training, being always easily accessible from anywhere and enables being extremely economical.

Today there are Trend Web Applications in many different areas. There are many web applications are available for content development; bubbl.us, infogr.am etc.,for managing content; thinglink, tumblr, etc., for sharing content, Easyclass, DropBox and etc. But Edmodo has been designed to cover all these applications. It provides content development, managing developed content and the opportunity to share this content.

Edmodo, as well as providing ease of use thanks to Facebook similarity, is also quite common among students and teachers in different locations of the world since it is a secure medium that people can provide access for only educational purpose.

The main activities that can be done with Edmodo can be summarized as follows:

-With Edmodo, teachers can create a group or class giving parent code with group code as in Figure 1.

Created groups can be seen from following figure. 


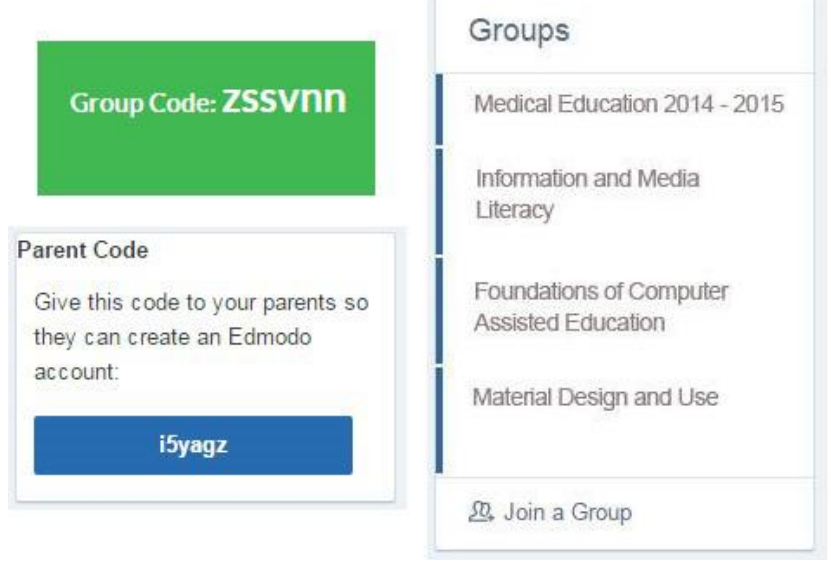

Figure 1: Left Menus of Edmodo Homepage

- You can write and share these notes to the window in Figure 2.

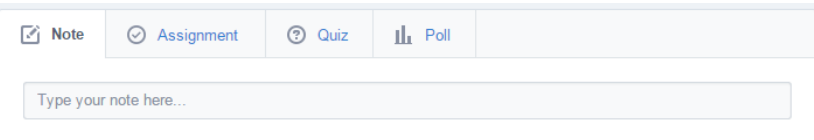

Figure 2. Edmodo Note Writing Window

- You can give homework and grade to your students from homework area in Figure 2.

- You can give feed back instantly doing quizzes from quiz area in Figure 2.

- You can get the idea about a topic of your students applying a questionnaire from survey area in Figure 2.

- In order to facilitate the tracking of students from the warning area in Figure 2, you can add a small notice as e warnings.

- As shown in Figure 3 and 4 by means of library and backpacks, you can store or share your documents.

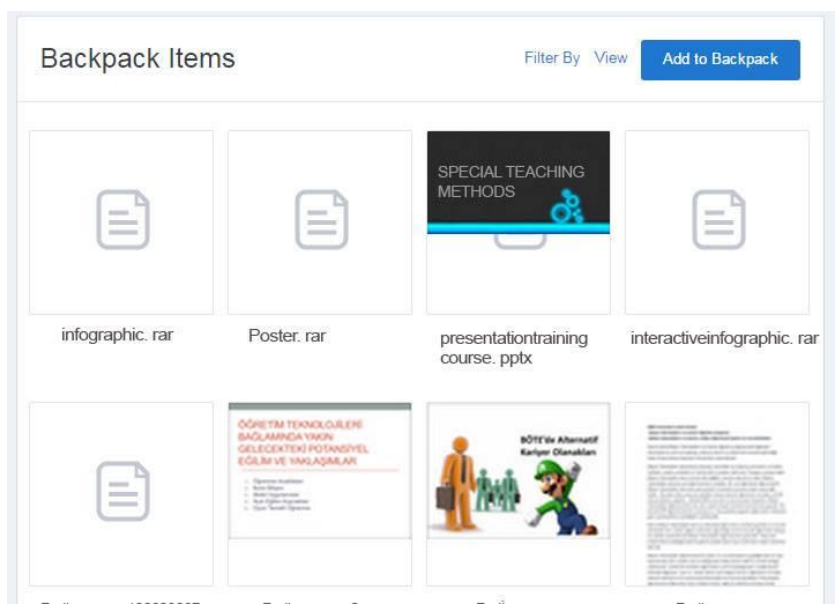

Figure 3: Edmodo back pack

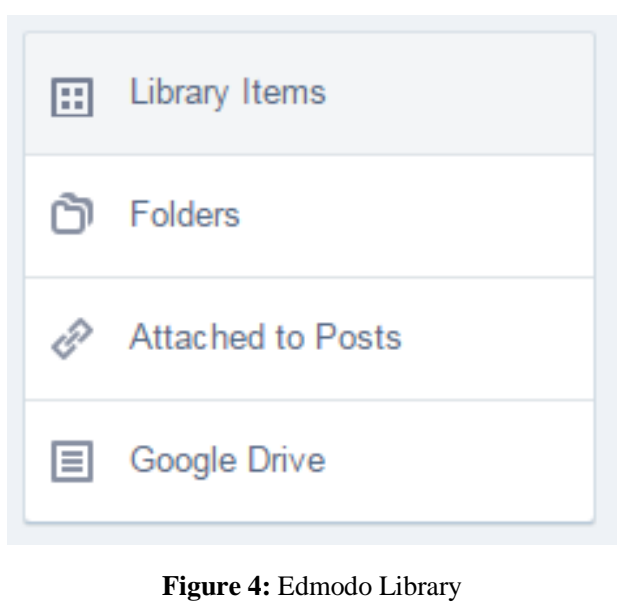

Today, one of the problems encountered in the face to face training is being overrun difficulties of shy students' participation in the course with Edmodo that supports online learning and by giving social presence sense, social presence has been provided. In this way, students are able to find the comfort with Edmodo that they could not find in the actual class. Education integration with social networks via Edmodo,with mobile applications of the software,providing the possibility of sharing information at every where and every time makes learning with Edmodo more entertaining. In addition,being accessible from everywhere of Edmod, provides parents for viewing the development of the children of the parents easily. As well as using Edmodo as singlehanded,in addition to on behalf of further enriching of education, there are other web applications. As examples;

Hapyak Interactive Video Creation Platform

Today, interactive videos are among the most widely being used education technologies. Since it appeals audio-visual senses simultaneously, usage of it in education is very effective. More importantly, providing interaction among the audience with content, it provides a more active and permanent learning opportunity.

For doing interactive videos, there are programs like camtasia, captivate etc. on. programs are also available. But since hapyak does not require any software installation, using it is always possible at everywhere and everytime as online.

With Hapyak web application, as in Figure 5,documents such as quiz questions that placed into the video, course sections, links, pictures, articles, and etc. can be recorded on video. By this means, thereby adding interaction to the videos that have been used during the course, it is provided that the students participate in the course with higher interest.

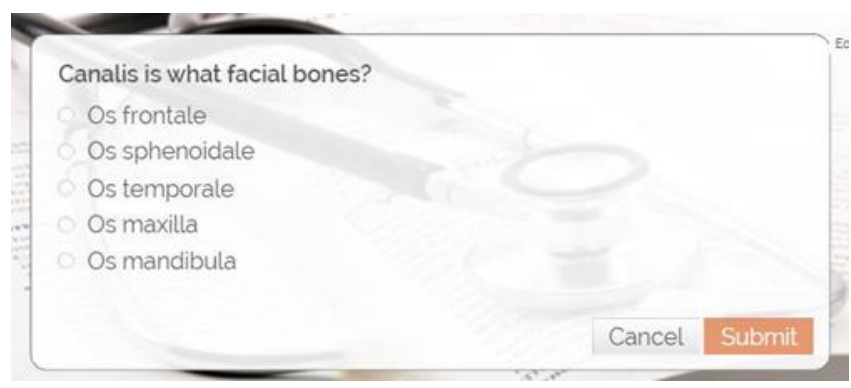

Figure 5. Hapyak Sample Quiz Question

The disadvantage of Hapyak application is its being a bit complicated. For someone who will use the application for the first time,after doing his work when he or she has wanted to take a printout, it is likely to encounter with problems Online Testing and Instant Reporting with Socrative 
Socrative is a freeware 2.0 web tool, that you can get instant feedback in class or at different environments you have determined and with the questions that you've prepared and you can do survey, you can apply online exam instantly and share the results, you can do online testing as a group.

When the test is completed you can receive reports on the basis of student or question immediately. In particular it has a useful structure for education with tablet. You can prepare questions entering the website of the application from your desktop.

The application which is used in two different ways called Socrative Student and Socrative Teacher can be used both in Android and IOS platforms also through any Internet browser.. Membership of student is not required for the student in the Socrative Student application. A student who open Socrative application by one of the tool such as mobile phone, tablet computer and etc. need only room number given by the teacher. After making entry into the room and the test has been started by the teacher, students will be able to give answer the questions comfortably as in Figure 6.

Canalis is what facial bones?
\begin{tabular}{|c|l|l|}
\hline A & Os frontale \\
\hline C & Os sphenoidale \\
\hline C & Os temporale \\
\hline D & Os maxilla \\
\hline E & Os mandibula \\
\hline
\end{tabular}

\section{SUBMIT ANSWER}

Figure 6. Socrative Student Problem Solving Screen

Socrativ Teacher is a platform at which teacher can prepare questions and apply test as in Figure 7. 3 different question types as multiple choice, true-false question and short answer can be prepared. You can share the test that you have prepared with your colleague or copy the test that they have prepared to your own account.

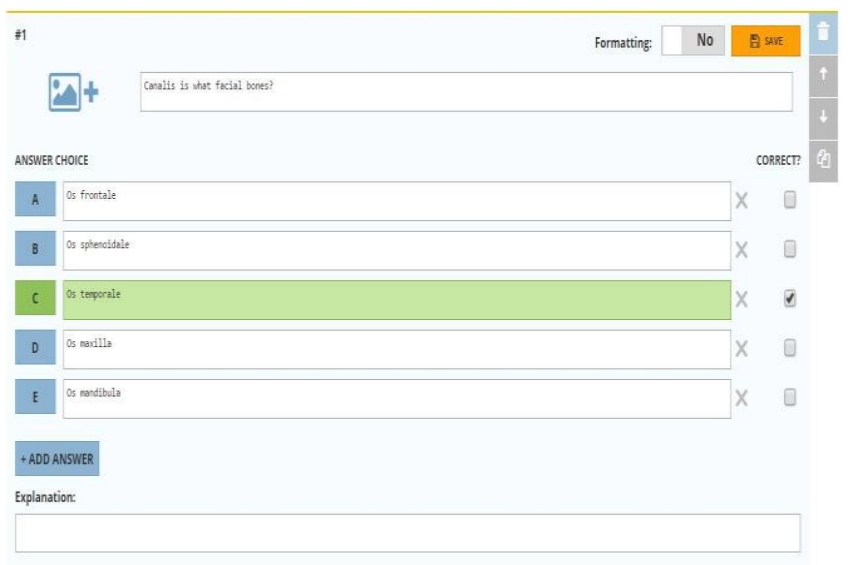

Figure 7. Socrative Teacher Question Preparation Screen
Bubble.us is an easy and free application that is used for creating concept map without requiring a special program. Creation of colorful concept map, as shown in Figure 8, offers many highly interactive services such as to be saved as a picture of creating concept maps, to be shared with friends of the product, print, to be integrated to the website or blog. The only thing that should be done is taking notes and connecting the writings using balloons on the issues that you think and associate them. If you wish, you can use different colors, you can save your maps in png or jpeg format or you can print from your printer. If you become registered user, you can save your maps that you have not completed yet, and then you can continue to complete whenever you register.

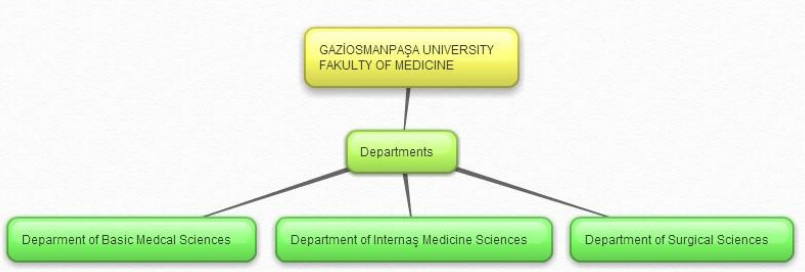

Figure 8: A Sample of Mindmap Application

\section{References}

[1] Elitaş, C., \& Özdemir, S. (2014). Bulut Bilişim ve Muhasebede Kullanımı. Muhasebe Bilim Dünyası Dergisi,16(2). 93-108.

[2] Kavzoğlu, T., \& Şahin, E. K. Bulut Bilişim Teknolojisi ve Bulut CBS Uygulamaları. IV. Uzaktan Algılama ve Coğrafi Bilgi Sistemleri Sempozyumu (UZAL-CBS 2012), 16-19 Ekim 2012, Zonguldak.

[3] Soykan, E. (2013). Mobil Destekli Öğrenme Etkinliklerinin Öğretmen Adaylarının Başarılarına, Yaşam Boyu Öğrenme ve Mobil Öğrenme Yeterliliklerine Etkisi. Yakın Doğu Üniversitesi Eğitim Bilimleri Enstitüsü Bilgisayar ve Öğretim Teknolojileri. Yüksek Lisans Tezi. Lefkoşa.

[4] Yıldız, Ö. R. (2010). Bilișim Dünyasının Yeni Modeli: Bulut Bilişim (Cloud Computing) ve Denetim. Sayıştay Dergisi, 74 75.

[5] Turan, M. (2014). Bulut Bilişim ve Riskler. Türkiye Kalkınma Bankası Yayını, 72. 3-13.M. Shell. (2002) IEEEtran homepage on CTAN. [Online]. Available: http://www.ctan.org/texarchive/macros/latex/contrib/supported/IEEEtran/

[6] FLEXChip Signal Processor (MC68175/D), Motorola, 1996.

[7] "PDCA12-70 data sheet," Opto Speed SA, Mezzovico, Switzerland.

[8] A. Karnik, "Performance of TCP congestion control with rate feedback: TCP/ABR and rate adaptive TCP/IP," M. Eng. thesis, Indian Institute of Science, Bangalore, India, Jan. 1999.

[9] J. Padhye, V. Firoiu, and D. Towsley, "A stochastic model of TCP Reno congestion avoidance and control," Univ. of Massachusetts, Amherst, MA, CMPSCI Tech. Rep. 99-02, 1999.

[10] Wireless LAN Medium Access Control (MAC) and Physical Layer (PHY) Specification, IEEE Std. 802.11, 1997.

\subsection{Bubbl.Us Mindmap Application}

